\title{
Professional Intervention of Social
} Group Work Using Preventive Rehabilitative Approach And Mitigation of Emotional Divorce Risks For The Newlywed Women.

\section{Hanaa Aref Ahmed Mohamed (PhD)}

Assistant Professor, Social Group Work Department

Faculty of Social Work- Aswan University 
The Egyptian Journal of Social Work (EJSW) https://ejsw.journals.ekb.eg/e ISSN: 2356-9204 Vol 11, Issue.1, January2021 
The Egyptian Journal of Social Work (EJSW) https://ejsw.journals.ekb.eg/e

ISSN: 2356-9204

Vol 11, Issue.1, January2021

Abstract

The current study aims to reveal the impact of the professional intervention of social group work using preventive rehabilitative approach and mitigation of emotional divorce risks for the newlywed women. The study sample consists of two groups, a pilot group and a control group; each consisting of (13) newlywed women with marriage periods ranging from (2) to (4) years and ages ranging from (27) to (33) years. Parity was made between the two groups in terms of age, duration of marriage and emotional divorce risks (social, psychological and techno-sexual).emotional divorce risks' scale was designed and its standard characteristics were calculated. The professional intervention program of social group work was designed from the perspective of the preventive rehabilitative approach consisting of (30) sessions. The professional intervention program was applied to the pilot group without the control group, where differences between the pre and post measurements were found on applying the scale. The results proved the effectiveness of the professional intervention of social group work using the preventive rehabilitative approach and mitigation of emotional divorce risks for the newlywed women.

Key words: preventive rehabilitative approach, newlywed woman, emotional divorce.

Introduction:

Marriage is beneficial to the society because it is the foundation of a family and the building block of a society. Marriage between a man and a woman is vital to the stability and preservation of the society in which a father and mother raise and nurture children. Marriage is not just the coming together of the two individuals. There is much more to it. To sustain a marriage, it is important that there is effort from both sides; a successful marriage is like a good recipe whose main ingredients are love, good communication, commitment understanding, concern, care and togetherness. Most marriage partners marry in love with intention to honor the vow while many issues develop over time such as ineffective communication, extramarital affairs, jealousy, relationship abuse and sexual issues which lead to divorce (Esere, 2014, p585). Marriage is the greatest social educator of children. It is the institution that most effectively teaches the civic virtues of honesty, loyalty, trust, self-sacrifice, personal responsibility, and respect for others. The virtues cultivated between men and women in marriage, and between parents and the children, radiate outward into civil society. They deepen in married men and women strong 
The Egyptian Journal of Social Work (EJSW) https://ejsw.journals.ekb.eg/e ISSN: 2356-9204

Vol 11, Issue.1, January2021

habits of devotion to civic life (Wilcox, 2002, p 3). Marriage, especially a good marriage, supports mental health. (Theresa Notare \& McCord, 2012, p3).

Considering family system importance as the first structure of society where the foundation of training and education of children and legal relations between men and women as a legitimate standard were is founded there. The importance of attention and maintain such this structure considering the role of psychological mental, emotional, social and behavioral of that and children modeling in an emotional environment are clearly observable (Barnes\& Gorilla, 2003).

Internal quality of families has an important role in forming attitudes and family social feedback and the basis of family internal relationships is based on the relationship between husband and wife. Emotional divorce is a sign of problem in a healthy and correct relationship between husband and wife. This relationship problem in family can be expanded in society and destroy human relationship. When family foundation falters the moral and social basis of all social system will be faltered and society will be led to different problems so checking emotional divorce problem is crucially important.(Amiri, 2015, p783).

Divorce is one of the most important family injuries, but formal divorce statistics cannot show the rate of failure of spouses in marriage because besides that the bigger statistics are specified to emotional divorces which means off lives and hollow families that man and woman are living together in the cold but they don't get divorced (Golzari, 2010). Divorce is starting by either emotional or psychological divorce and then, ending by legal divorce, but majority of couple's relationship beings and persists in an emotional divorce. (Al-Ubaidi, 2017,p4).Therefor in emotional divorce couples live only under one roof while their relationships have completely interrupted or without desire and satisfaction.

Emotional divorce leads to further separation, which increases the psychological pressure on the couple. It also increases the difference and problems between them. One or both becomes irritable and behaves erratically and can become harmful to the other party. $\mathrm{He} / \mathrm{she}$ cannot coexist with him, making it more difficult to sustain life between them (Attieh, 2009).

Emotional divorce passes through several stages, beginning with the loss of affection and love and then partial abandonment of the emotional practices of all types gradually, to complete abandonment. It also involves any sexual relationship, and living outside the home 
and neglecting maintenance and care. This way, the wife is neither divorced nor married (Al-Hakbani, 2013).

The problem of emotional divorce is that it is an internal problem that is not explicitly visible, and its occurrence does not necessarily lead to divorce and formal separation between spouses. Emotional divorce is the negative form of the marital relationship and arises as a result of the ongoing differences between the spouses because of the failure of one or both of them to satisfy the needs of the other party. The negative relationship obstructs the development of emotional life between the spouses and leads to further divergence and widening gap between them, which negatively impacts on their treatment of each other of all family members (Jarwan \& Al freha,2020,p76). The newlywed wife or the one who is about to get married often resorts to her friends and colleagues to obtain information and experiences on marital and sexual relations in order to avoid talking to a family member

The preventive rehabilitation role has gained the attention of specialists in the social work as it achieves the process of accompaniment between providing services to all normal and nonnormal members of society and the processes of modernization and life change in society. In addition, the tenor of this role leads to the try to avoid problems before they occur through taking the necessary measures in order not to reappear or reoccur (Abdo, Hassan,2006).

By practicing the social group work through programs and activities, it is possible to achieve basic levels of prevention, being an attempt to prevent or avoid the problem. It is also the result of social and psychological factors affecting personality and the environment where a person lives. This aims to achieve adaptation for the individual and society using preventive procedures that include different programs to achieve the same (Fahmy\& Attia,2003, p. 91). The group is the mediator through which changes in the attitudes, skills, behavior, abilities and capabilities of members within the group are brought about (Gutierrez, Garvin, 2004, p. 400).

Mansour (1992) indicates that one reason for the emergence of emotional divorce is spouses' intransigence where each of them wants everything for himself. Neither of them knows that marital life is based on two parties, each of them has his duties that are the rights of the other, and his rights that are the duties of the other.

Al-Bahi (2004) emphasizes the necessity of providing newly formed families with knowledge and skills related to family interactions and relationships, dealing with family problems, methods of raising 
children, and how to deal with life events. Al-Zawawy (2011) The study tries to reach a proposed role for the social group workers to provide the newlywed with family coping skills . Rizk (2013) confirmed that social work has an important role in protecting the family through its preventive and curative role, where the family that receives social and guidance services is more stable and active in society.

Al-Tanbary (2017) aimed to define the relationship between the use of positive family dialogue mechanisms in social group work program and the development of wives 'ability to deal with their marital problems. Al-Otaiby (2018) aimed to identify the manifestations, symptoms and reasons of emotional divorce and the role of spouses in avoiding emotional divorce. It also aimed to identify the attitudes of spouses towards the professional assistance provided to them. In light of research results, Hashem (2020) aimed to test the effectiveness of life model from the perspective of general practice in social work in alleviating the pressures experienced by divorced women.

The researcher has utilized the previous studies to understand, formulate and prepare study questions, problem and tools. However, the current study differs from the mentioned studies in the following:

- None of the previous studies touched on mitigating the risks of emotional divorce for a newlywed woman, which called on the researcher to conduct the current study.

- The current study differs from the previous studies as it uses the preventive rehabilitative approach to mitigate the risks of emotional divorce for the newlywed woman, which is also not covered in the previous studies.

Given the above studies, it turns out that the professional intervention of social group work from the perspective of the preventive rehabilitative approach to mitigate the risks of emotional divorce for the newlywed woman did not have enough attention. This called on the researcher to professionally intervene based on the role of social group work in bringing about cognitive, skill and behavioral changes to the newlywed women, which contributes to improving the quality of family performance. Accordingly, the study problem was determined to be the following question: "Does the professional intervention of social group work using the preventive rehabilitative approach lead to mitigating the risks of emotional divorce for the newlywed woman?" 
The Egyptian Journal of Social Work (EJSW) https://ejsw.journals.ekb.eg/e

ISSN: 2356-9204

Vol 11, Issue.1, January2021

Study importance:

1. Indicating the most prominent risks (social, psychological and techno-sexual) of emotional divorce facing the newlywed women, and put them in the focus of attention of officials in the social fields and the bodies responsible for family reform in line with family policies and sustainable development.

2. The family shall be given the most protection and support while revealing the factors of family's solidity, the coherence of its structure and its ability to embrace its authentic cultural heritage, being the important element in preserving its personalities and its readiness to the dynamic interaction with all changes.

3. The scarcity of studies addressing the professional intervention of social group work using the preventive rehabilitative approach and mitigation of emotional divorce risks (social, psychological and technical nationality) for the newlywed women in the social work in general and the social group work in particular, to the most of researcher's knowledge.

4. The study results may help those working in family courts and specialists of marital counseling in designing programs or holding a set of educational seminars for both young men and women who are about to marry to reduce emotional divorce and the generally increasing divorce rates in the Egyptian society.

Study objectives: The main objective of the study is:

"Identifying the relationship between professional intervention of social group work using the preventive rehabilitative approach and mitigating the risks of emotional divorce for the newlywed woman". This is achieved through achieving the following sub-objectives:

- Identifying the relationship between the professional intervention of social group work using the preventive rehabilitative approach and mitigating the social risks of emotional divorce for the newlywed woman;

- Identifying the relationship between the professional intervention of social group work using the preventive rehabilitative approach and mitigating the psychological risks of emotional divorce for the newlywed woman; and

- Identifying the relationship between the professional intervention of social group work using the preventive rehabilitative approach and mitigating the techno-sexual risks of emotional divorce for the newlywed woman. 
The Egyptian Journal of Social Work (EJSW) https://ejsw.journals.ekb.eg/e

ISSN: 2356-9204

Vol 11, Issue.1, January2021

Study hypotheses: The main hypothesis of this study is:

"There is a positive statistically significant relation between the professional intervention of social group work using the preventive rehabilitative approach and mitigating the risks of emotional divorce for the newlywed woman".

The following four sub-hypotheses stem from the main hypothesis:

- There are no statistically significant differences between the average performance of the pilot and control groups on the scale in the pre-measurement.

- There are statistically significant differences between the average performance of the pilot and control groups on the scale in the pre and post measurements upon the professional intervention of social group work using the preventive rehabilitation approach with the newlywed women groups.

- There are no statistically significant differences between the average performance of the control group on the scale in the pre and post measurements.

- There are statistically significant differences between the average performance of the pilot group and the control group on the scale upon the professional intervention of social group work using the preventive rehabilitation approach with the newlywed women groups.

Study concepts: The researcher defined the procedural concepts of the study as follows:

Preventive rehabilitative approach: A modern approach to the way of working with groups. It is used to bring about types of changes in the wife's personality and the surrounding social environment. The group plays an important and influential role in the life of that type of group as a result of the social and psychological reasons they experienced. Thus, the group is used as a means of pressure, being an element of this approach, in order to achieve positive effects in the field of changing non-adaptive behaviors. The social group work specialist uses various methods of influence to change some of group's characteristics to help members reduce the risks of emotional divorce, including methods of behavior modification, problem solving and self-learning. This approach focuses on the cognitive, behavioral and values aspect associated with the risks of emotional divorce.

emotional divorce: It is a kind of response that involves the physical departure and the non-consideration of the other party who is treated as he/she does not exist(Kafafi,1999). It is procedurally defined as the 
The Egyptian Journal of Social Work (EJSW) https://ejsw.journals.ekb.eg/e ISSN: 2356-9204

Vol 11, Issue.1, January2021

overall degree obtained by the respondent on the emotional divorce scale used in this study.

Newlywed woman: A wife associated with a man (husband) under a legal marriage contract. Her marriage duration ranges from (2) to (4) years, and her age ranges from (27) to (33) years. She had never been married before. She has or does not have children and may need to awareness of emotional divorce risks.

Procedures:

Study type: This study is a quasi-experimental study based on reaching the relationship between the independent variable represented in the professional intervention of social group work using the preventive rehabilitative approach and the dependent variable represented in the mitigation of emotional divorce risks .

The approach used: In line with the study type, the approach used is the experimental approach, using the pre \& post experiment with two groups, a pilot group and a control group, taking into account experimental control.

Study tools: The tools of this study are represented in:

a. Scale of emotional divorce risks; and

b. Periodic reports.

a. Scale of emotional divorce risks : It is the primary tool in this study. Scale is an appropriate tool in such a study that belongs to quasiexperimental studies where it is mitigating the risks of emotional divorce among sample individuals by calculating the difference between the pre and post measurements of the pilot and control groups. The researcher has designed the emotional divorce risk scale.

Table (1)Correlation coefficients between each phrase and the total of emotional divorce risk scale

\begin{tabular}{|l|l|l|l|l|l|}
\hline $\begin{array}{l}\text { Phrase } \\
\text { No. }\end{array}$ & $\begin{array}{l}\text { Correlation } \\
\text { coefficient }\end{array}$ & $\begin{array}{l}\text { Significanc } \\
\text { e }\end{array}$ & $\begin{array}{l}\text { Phrase } \\
\text { No. }\end{array}$ & $\begin{array}{l}\text { Correlation } \\
\text { coefficient }\end{array}$ & $\begin{array}{l}\text { Significanc } \\
\text { e }\end{array}$ \\
\hline 1 & 0.752 & $* *$ & 16 & 0.653 & $* *$ \\
\hline 2 & 0.645 & $* *$ & 17 & 0.546 & $*$ \\
\hline 3 & 0.805 & $* *$ & 18 & 0.555 & $*$ \\
\hline 4 & 0.857 & $* *$ & 19 & 0.756 & $* *$ \\
\hline 5 & 0.658 & $* *$ & 20 & 0.518 & $* *$ \\
\hline 6 & 0.515 & $*$ & 21 & 0.690 & $* *$ \\
\hline 7 & 0.418 & $*$ & 22 & 0.789 & $* *$ \\
\hline 8 & 0.495 & $* *$ & 23 & 0.495 & $*$ \\
\hline 9 & 0.698 & $* *$ & 24 & 0.706 & $* *$ \\
\hline 10 & 0.700 & $* *$ & 25 & 0.701 & $* *$ \\
\hline 11 & 0.645 & $* *$ & 26 & 0.630 & $* *$ \\
\hline 12 & 0.611 & $* *$ & 27 & 0.802 & $* *$ \\
\hline 13 & 0.745 & $* *$ & 28 & 0.586 & $* *$ \\
\hline
\end{tabular}




$\mid \begin{aligned} & \mid \begin{array}{l}\text { The Egyptian Journal of Social Work (EJSW) https://ejsw.journals.ekb.eg/e } \\
\text { Vol 11, Issue.1, January2021 }\end{array} \\
& \text { ISSN: } 2356-9204\end{aligned}$
\begin{tabular}{|l|l|l|l|l|l|}
\hline $\begin{array}{l}\text { Phrase } \\
\text { No. }\end{array}$ & Correlation & Significanc & Phrase & Correlation & Significanc \\
coefficient & e & No. & coefficient & e \\
\hline 14 & 0.613 & $* *$ & 29 & 0.690 & $* *$ \\
\hline 15 & 0.700 & $* *$ & 30 & 0.759 & $* *$ \\
\hline
\end{tabular}

Table (1) shows that correlation coefficient values are high and significant at significance $(0.01)$ and $(0.05)$, which indicates the sincerity and reliability of the scale to an appropriate degree.

Table (2)Internal consistency between scale variables and total scale score $(\mathbf{n}=10)$

\begin{tabular}{|l|l|l|l|}
\hline No. & Dimensions & $\begin{array}{l}\text { Correlation } \\
\text { coefficient }\end{array}$ & Significance \\
\hline 1 & Social risks dimension & 0.789 & $* *$ \\
\hline 2 & Psychological risks dimension & 0.845 & $* *$ \\
\hline 3 & Techno-sexual risks dimension & 0.856 & $* *$ \\
\hline 4 & Scale as a whole & 0.830 & $* *$ \\
\hline
\end{tabular}

It is clear from the above table (2) that tool dimensions are statistically significant at a significance of (0.01) for each dimension separately. Thus, the tool has an appropriate level of sincerity and reliability.

Table (3)Statistical sincerity of the scale as a whole for reliability coefficient $(\mathbf{n}=\mathbf{1 0})$

\begin{tabular}{|l|l|l|}
\hline No. & Dimensions & Square root \\
\hline 1 & Reliability coefficient ( Cronbach's alpha) & 0.948 \\
\hline 2 & Split-half reliability coefficient & 0.954 \\
\hline
\end{tabular}

b. Periodic reports: The researcher recorded the periodic reports of the pilot group meetings and analyzed their content.

Sampling procedures: The study sample was collected from (99) women upon excluding (10) women to whom scale reliability was applied together with (63) women who did not meet the previously mentioned sampling conditions. The number of sample members thus became (26) women to whom the scale was applied. The sample was determined upon measurement so that the women with low scores on the scale were chosen. Those are (13) members chosen upon excluding the cases who did not meet sampling conditions. The researcher relied on the following sampling determinants:

- $\quad$ Woman's age shall range from (27) to (33) years.

- $\quad$ She must have been married for at least $(2-4)$ years.

- $\quad$ She had never been married before.

- $\quad$ Pilot group members were chosen considering pairing and achieving homogeneity between the two groups in a set of factors (e.g. age and duration of marriage). 
The Egyptian Journal of Social Work (EJSW) https://ejsw.journals.ekb.eg/e

ISSN: 2356-9204

Vol 11, Issue.1, January2021

Study scopes:

Spatial scope: El-Shatt village, Daru, Aswan.

Humanitarian scope: It is intended to define the study sampling scope from which (26) women who met sampling conditions in terms of age and duration of marriage were selected and divided into two groups, a pilot group and a control group.

Chronological scope: It is the period took by the professional intervention and experimentation process (from 5/11/2019 to 9/1/2020 AD).

Second: Study hypotheses' results:

Table (4)Distribution of the study sample for the pilot and control group in terms of type, using T-test $(n=26)$

\begin{tabular}{|l|l|l|l|l|l|l|}
\hline Dimensions & Groups & $\mathbf{N}$ & $\begin{array}{l}\text { Arithmetic } \\
\text { average }\end{array}$ & $\begin{array}{l}\text { Standard } \\
\text { deviation }\end{array}$ & $\mathbf{T}$ & Significance \\
\hline \multirow{2}{*}{ Type } & Control & 13 & 1.31 & 0.480 & 0.805 & Insignificant \\
\cline { 2 - 7 } & Pilot & 13 & 1.46 & 0.519 & 0.46 \\
\hline
\end{tabular}

The above table shows that there are no statically significant differences between the pilot and control groups in terms of type where (T) equals (0.805) and is insignificant, which reflects the homogeneity of the two groups.

Table (5)Significance of the differences between the premeasurement of the pilot group and the control group on the Eimotional divorce risk scale using the $T$-test $(n=26)$

\begin{tabular}{|c|c|c|c|c|c|c|}
\hline Dimensions & Groups & $\mathbf{n}$ & $\begin{array}{l}\text { Arithmetic } \\
\text { average }\end{array}$ & $\begin{array}{l}\text { Standard } \\
\text { deviation }\end{array}$ & $\mathbf{T}$ & Significance \\
\hline \multirow{2}{*}{ Social risks } & Control & 13 & 22.77 & 4.19 & \multirow{2}{*}{0.462} & \multirow{2}{*}{ Insignificant } \\
\hline & Pilot & 13 & 22 & 4.30 & & \\
\hline \multirow{2}{*}{$\begin{array}{l}\text { Psychological } \\
\text { risks }\end{array}$} & Control & 13 & 21.38 & 4.19 & \multirow{2}{*}{1.730} & \multirow{2}{*}{ Insignificant } \\
\hline & Pilot & 13 & 23.92 & 3.23 & & \\
\hline \multirow{2}{*}{$\begin{array}{l}\text { Techno- } \\
\text { sexual risks }\end{array}$} & Control & 13 & 22.08 & 3.12 & \multirow{2}{*}{1.127} & \multirow{2}{*}{ Insignificant } \\
\hline & Pilot & 13 & 23.38 & 2.78 & & \\
\hline \multirow{2}{*}{$\begin{array}{l}\text { Dimensions } \\
\text { as a whole }\end{array}$} & Control & 13 & 69.31 & 8.78 & \multirow{2}{*}{0.884} & \multirow{2}{*}{ Insignificant } \\
\hline & Pilot & 13 & 66.23 & 8.96 & & \\
\hline
\end{tabular}

The above table shows that:

There are no statistically significant differences between the newlywed woman's performance before the professional intervention using the emotional divorce risk scale for the benefit of the control and pilot groups. The arithmetic average of the pilot group amounted to (66.23) with a standard deviation (8.96), while arithmetic average for the control group amounted to (69.31) with a standard deviation (8.78). The value of (T)was (0.884), which is insignificant. This confirms the validity of the hypothesis that there are no differences in the pre-measurement for the pilot and control groups on the emotional 
The Egyptian Journal of Social Work (EJSW) https://ejsw.journals.ekb.eg/e

ISSN: 2356-9204

Vol 11, Issue.1, January2021

divorce risk scale because they were not subject to the professional intervention program.

As for the social risk dimension, there are no statistically significant differences between the newlywed woman's performance before the professional intervention using the emotional divorce risk scale for the benefit of the control and pilot groups. The arithmetic average of the pilot group was (22) with a standard deviation (4.30), while the arithmetic average of the control group was (22.77) with a standard deviation (4.19). The value of (T)was (0.462), which is insignificant. This confirms the validity of the hypothesis that there are no differences in the pre-measurement of the pilot and control groups on the emotional divorce risk scale because they were not subject to the professional intervention program. With regard to psychological risk dimension, there are no statistically significant differences between the newlywed woman's performance before the professional intervention using the emotional divorce risk scale for the benefit of the control and pilot groups. The arithmetic average of the pilot group was (23.92) with a standard deviation (3.23), while the arithmetic average of the control group was (21.38) with a standard deviation (4.19). The value of (T) was (1.730), which is insignificant. This confirms the validity of the hypothesis that there are no differences in the pre-measurement of the pilot and control groups on the emotional divorce risk scale because they were not subject to the professional intervention program. With regard to the techno-sexual risk dimension, there are no statistically significant differences between the newlywed woman's performance before the professional intervention using the emotional divorce risk scale for the benefit of the control and pilot groups. The arithmetic average of the pilot group was (23.38) with a standard deviation (2.78), while the arithmetic average of the control group was (22.08) with a standard deviation (3.12). The value of (T) was (1.127), which is insignificant. This confirms the validity of the hypothesis that there are no differences in the pre-measurement of the pilot and control groups on the emotional divorce risk scale because they were not subject to the professional intervention program.

The second hypothesis:

There are no significant differences between the average scores of the cases of the control group before and after the professional intervention program using the emotional divorce risk scale. 
The Egyptian Journal of Social Work (EJSW) https://ejsw.journals.ekb.eg/e

ISSN: 2356-9204

Vol 11, Issue.1, January2021

Table (6)Significance of the differences between the average scores of the control group before and after the professional intervention program on the emotional divorce risk scale using the T-test $(\mathbf{n}=\mathbf{2 6})$

\begin{tabular}{|c|c|c|c|c|c|c|}
\hline Dimensions & Groups & $\mathrm{n}$ & $\begin{array}{l}\text { Arithmetic } \\
\text { average }\end{array}$ & $\begin{array}{l}\text { Standard } \\
\text { deviation }\end{array}$ & $\mathrm{T}$ & Significance \\
\hline \multirow{2}{*}{ Social risks } & Pre & 13 & 22.77 & 4.19 & \multirow{2}{*}{1.079} & \multirow{2}{*}{ Insignificant } \\
\hline & Post & 13 & 24.15 & 2.38 & & \\
\hline \multirow{2}{*}{$\begin{array}{l}\text { Psychological } \\
\text { risks }\end{array}$} & Pre & 13 & 21.38 & 4.19 & \multirow{2}{*}{2.486} & \multirow{2}{*}{ Insignificant } \\
\hline & Post & 13 & 24.46 & 2.40 & & \\
\hline \multirow{2}{*}{$\begin{array}{l}\text { Techno-sexual } \\
\text { risks }\end{array}$} & Pre & 13 & 22.08 & 3.12 & \multirow{2}{*}{2.589} & \multirow{2}{*}{ Insignificant } \\
\hline & Post & 13 & 25 & 3.08 & & \\
\hline \multirow{2}{*}{$\begin{array}{l}\text { Dimensions as } \\
\text { a whole }\end{array}$} & Pre & 13 & 66.23 & 8.96 & \multirow{2}{*}{2.620} & \multirow{2}{*}{ Insignificant } \\
\hline & Post & 13 & 73.62 & 6.79 & & \\
\hline
\end{tabular}

The above table shows that:

There are no statistically significant differences between the average scores of the cases of the control group before and after the professional intervention program using the emotional divorce risk scale .The arithmetic average of the pre-measurement amounted to (66.23) with a standard deviation (8.96), while the arithmetic average of the post-measurement amounted to (73.62) with a standard deviation (6.79). The value of (T)was (2.620), which is insignificant. This confirms the validity of the hypothesis that there are no significant differences between the average scores of the cases of the control group before and after the professional intervention program using emotional divorce risk scale, as it was not subject to the professional intervention program.

With respect to the social risk dimension, there are no statistically significant differences between the average scores of the cases of the control group before and after the professional intervention program using the emotional divorce risk scale. The arithmetic average of the pre-measurement amounted to (22.77) with a standard deviation (4.19), while the arithmetic average of the post-measurement amounted to (24.15) with a standard deviation (2.38).The value of (T)was (1.079), which is insignificant. This confirms the validity of the hypothesis that there are no significant differences between the average scores of the cases of the control group before and after the professional intervention program using emotional divorce risk scale, as it was not subject to the professional intervention program.

With respect to the psychological risk dimension, there are no statistically significant differences between the average scores of the cases of the control group before and after the professional 
The Egyptian Journal of Social Work (EJSW) https://ejsw.journals.ekb.eg/e

ISSN: 2356-9204

Vol 11, Issue.1, January2021

intervention program using the emotional divorce risk scale. The arithmetic average of the pre-measurement amounted to (21.38) with a standard deviation (4.19), while the arithmetic average of the postmeasurement amounted to (24.46) with a standard deviation (2.40).The value of (T) was (2.486), which is insignificant. This confirms the validity of the hypothesis that there are no significant differences between the average scores of the cases of the control group before and after the professional intervention program using emotional divorce risk scale, as it was not subject to the professional intervention program.

With respect to the techno-sexual risk dimension, there are no statistically significant differences between the average scores of the cases of the control group before and after the professional intervention program using the emotional divorce risk scale. The arithmetic average of the pre-measurement amounted to (22.08) with a standard deviation (3.12), while the arithmetic average of the postmeasurement amounted to (25) with a standard deviation (3.08). The value of (T)was (2.589), which is insignificant. This confirms the validity of the hypothesis that there are no significant differences between the average scores of the cases of the control group before and after the professional intervention program using emotional divorce risk scale, as it was not subject to the professional intervention program. Based on the previous table, we conclude that there are no statistically significant differences between the average scores of the cases of the control group before and after the professional intervention program using the emotional divorce risk scale. This is due to their non-participation in the professional intervention program and the non-application of the methods of the professional intervention of social group work using the preventive rehabilitative approach.

The third hypothesis:

There are significant differences between the average scores of the cases of the pilot group in terms of the newlywed woman's performance before and after the professional intervention program using the emotional divorce risk scale in favor of the pilot group. 
The Egyptian Journal of Social Work (EJSW) https://ejsw.journals.ekb.eg/e ISSN: 2356-9204

Vol 11, Issue.1, January2021

Table (7)Significance of the differences between the average scores of the pilot group before and after the professional intervention program on the emotional divorce risk scale using the T-test $(n=26)$

\begin{tabular}{|c|c|c|c|c|c|c|}
\hline Dimensions & Groups & $\mathrm{N}$ & $\begin{array}{l}\text { Arithmetic } \\
\text { average }\end{array}$ & $\begin{array}{l}\text { Standard } \\
\text { deviation }\end{array}$ & $\mathrm{T}$ & Significance \\
\hline \multirow[b]{2}{*}{ Social risks } & Pre & 13 & 22 & 4.30 & \multirow[b]{2}{*}{$11.240 * *$} & \multirow{2}{*}{$\begin{array}{l}\text { Significant at } \\
\text { significance of } \\
(0.05)\end{array}$} \\
\hline & Post & 13 & 16.69 & 1.97 & & \\
\hline \multirow{2}{*}{$\begin{array}{l}\text { Psychological } \\
\text { risks }\end{array}$} & Pre & 13 & 23.92 & 3.23 & \multirow{2}{*}{$10.111 * *$} & \multirow{2}{*}{$\begin{array}{l}\text { Significant at } \\
\text { significance of } \\
(0.05)\end{array}$} \\
\hline & Post & 13 & 13.92 & 1.89 & & \\
\hline \multirow{2}{*}{$\begin{array}{l}\text { Techno- } \\
\text { sexual risks }\end{array}$} & Pre & 13 & 23.38 & 2.79 & \multirow[b]{2}{*}{$11.560 * *$} & \multirow{2}{*}{$\begin{array}{l}\text { Significant at } \\
\text { significance of } \\
(0.05)\end{array}$} \\
\hline & Post & 13 & 13.90 & 2.17 & & \\
\hline \multirow{2}{*}{$\begin{array}{l}\text { Dimensions } \\
\text { as a whole }\end{array}$} & Pre & 13 & 69.31 & 8.78 & \multirow[b]{2}{*}{$14.860 * *$} & \multirow{2}{*}{$\begin{array}{l}\text { Significant at } \\
\text { significance of } \\
(0.05)\end{array}$} \\
\hline & Post & 13 & 42.54 & 4.63 & & \\
\hline
\end{tabular}

The above table shows that:

There are statistically significant differences between the average scores of the pilot group cases in the newlywed woman's performance before and after the professional intervention using the emotional divorce risk scale in favor of the pilot group. The arithmetic average in the pre-measurement amounted to (69.31) with a standard deviation (8.78), while the arithmetic average in the post-measurement amounted to (42.54) with a standard deviation (4.63). The value of (T)was $\left(14.860^{* *}\right)$, which is significant at significance of $(0.05)$.This indicates the effectiveness of the professional intervention program and confirms the validity of the hypothesis that there are significant differences between the average scores of the pilot group cases in the newlywed woman's performance before and after the professional intervention using the emotional divorce risk scale in favor of the pilot group.

For the social risk dimension, there are statistically significant differences between the average scores of the pilot group cases in the newlywed woman's performance before and after the professional intervention using the emotional divorce risk scale in favor of the pilot group. The arithmetic average in the pre-measurement amounted to (22) with a standard deviation (4.30), while the arithmetic average in the post-measurement amounted to (16.69) with a standard deviation (1.97).The value of (T)was $(11.240 * *)$, which is significant at significance of (0.05).This indicates the effectiveness of the professional intervention program and confirms the validity of the 
The Egyptian Journal of Social Work (EJSW) https://ejsw.journals.ekb.eg/e

ISSN: 2356-9204

Vol 11, Issue.1, January2021

hypothesis that there are significant differences between the average scores of the pilot group cases in the newlywed woman's performance before and after the professional intervention using the emotional divorce risk scale in favor of the pilot group.

For the psychological dimension, there are statistically significant differences between the average scores of the pilot group cases in the newlywed woman's performance before and after the professional intervention using the emotional divorce risk scale in favor of the pilot group. The arithmetic average in the pre-measurement amounted to (23.92) with a standard deviation (3.23), while the arithmetic average in the post-measurement amounted to (13.92) with a standard deviation (1.89). The value of (T)was (10.111**), which is significant at significance of (0.05).This indicates the effectiveness of the professional intervention program and confirms the validity of the hypothesis that there are significant differences between the average scores of the pilot group cases in the newlywed woman's performance before and after the professional intervention using the Eimotional divorce risk scale in favor of the pilot group.

For the techno-sexual dimension, there are statistically significant differences between the average scores of the pilot group cases in the newlywed woman's performance before and after the professional intervention using the emotional divorce risk scale in favor of the pilot group. The arithmetic average in the pre-measurement amounted to (23.38) with a standard deviation (2.79), while the arithmetic average in the post-measurement amounted to (13.90) with a standard deviation (2.17). The value of (T)was $\left(11.560^{* *}\right)$, which is significant at significance of (0.05).This indicates the effectiveness of the professional intervention program and confirms the validity of the hypothesis that there are significant differences between the average scores of the pilot group cases in the newlywed woman's performance before and after the professional intervention using the emotional divorce risk scale in favor of the pilot group. From the previous table, we conclude that there are significant differences between the average scores of pilot group cases in the newlywed women's performance before and after the professional intervention using the emotional divorce risk scale in favor of the pilot group. This indicates the effectiveness of the professional intervention program and confirms the validity of the hypothesis that there are significant differences between the average scores of the pilot group cases in the newly married woman's performance before and after the professional intervention using the emotional divorce risk scale in favor of the pilot 


\begin{tabular}{||cr|}
\hline The Egyptian Journal of Social Work (EJSW) https://ejsw.journals.ekb.eg/e \\
ISSN: $2356-9204$ & Vol 11, Issue.1, January2021 \\
\hline
\end{tabular}

group. This is due to the social worker's use of the methods of the professional intervention program with the pilot group members and their commitment to the principles of social group work.

The fourth hypothesis:

There are significant differences between the average scores of the pilot and control groups after the professional intervention using the emotional divorce risk scale in favor of the pilot group.

Table (8)Significance of the differences between the post-measures of the pilot and control groups on the Emotional divorce risk scale using the T-test $(n=26)$

\begin{tabular}{|c|c|c|c|c|c|c|}
\hline Dimensions & Groups & $\mathrm{N}$ & $\begin{array}{l}\text { Arithmetic } \\
\text { average }\end{array}$ & $\begin{array}{l}\text { Standard } \\
\text { deviation }\end{array}$ & $\mathrm{T}$ & Significance \\
\hline \multirow{2}{*}{ Social risks } & Control & 13 & 24.15 & 2.38 & \multirow{2}{*}{$12.213 * *$} & \multirow{2}{*}{$\begin{array}{l}\text { Significant at } \\
\text { significance of } \\
(0.05)\end{array}$} \\
\hline & Pilot & 13 & 14.69 & 1.97 & & \\
\hline \multirow{2}{*}{$\begin{array}{l}\text { Psychological } \\
\text { risks }\end{array}$} & Control & 13 & 24.46 & 2.40 & \multirow{2}{*}{$14.530 * *$} & \multirow{2}{*}{$\begin{array}{l}\text { Significant at } \\
\text { significance of } \\
(0.05)\end{array}$} \\
\hline & Pilot & 13 & 13.92 & 1.89 & & \\
\hline \multirow{2}{*}{$\begin{array}{l}\text { Techno- } \\
\text { sexual risks }\end{array}$} & Control & 13 & 25 & 3.08 & \multirow[b]{2}{*}{$12.702 * *$} & \multirow{2}{*}{$\begin{array}{l}\text { Significant at } \\
\text { significance of } \\
(0.05)\end{array}$} \\
\hline & Pilot & 13 & 13.90 & 2.17 & & \\
\hline \multirow{2}{*}{$\begin{array}{l}\text { Dimensions } \\
\text { as a whole }\end{array}$} & Control & 13 & 73.62 & 6.79 & \multirow{2}{*}{$15.360 * *$} & \multirow{2}{*}{$\begin{array}{l}\text { Significant at } \\
\text { significance of } \\
(0.05)\end{array}$} \\
\hline & Pilot & 13 & 42.54 & 4.63 & & \\
\hline
\end{tabular}

The above table shows that:

There are statistically significant differences between the average scores of the pilot and control groups after the professional intervention using the emotional divorce risk scale in favor of the pilot group. The arithmetic average of the pilot group amounted to (42.54) with a standard deviation (4.63), while the arithmetic average of the control group amounted to (73.62) with a standard deviation (6.79).The value of (T)was $\left(15.360^{* *}\right)$, which is significant at significance of (0.05).This indicates the effectiveness of the professional intervention program and confirms the validity of the hypothesis that there are significant differences between the average scores of the pilot group cases and the control group cases after the professional intervention using the emotional divorce risk scale in favor of the pilot group.

For the social risk dimension, there are statistically significant differences between the average scores of the pilot and control groups after the professional intervention using the emotional divorce risk scale in favor of the pilot group. The arithmetic average of the pilot group amounted to (14.69) with a standard deviation (1.97), while the 
arithmetic average of the control group amounted to (24.15) with a standard deviation (2.38). The value of (T)was $\left(12.213^{* *}\right)$, which is significant at significance of (0.05). This indicates the effectiveness of the professional intervention program and confirms the validity of the hypothesis that there are significant differences between the average scores of the pilot group cases and the control group cases after the professional intervention using the emotional divorce risk scale in favor of the pilot group.

For the psychological risk dimension, there are statistically significant differences between the average scores of the pilot and control groups after the professional intervention using the emotional divorce risk scale in favor of the pilot group. The arithmetic average of the pilot group amounted to (13.92) with a standard deviation (1.89), while the arithmetic average of the control group amounted to (24.46) with a standard deviation (2.40). The value of (T)was $(14.530 * *)$, which is significant at significance of (0.05).This indicates the effectiveness of the professional intervention program and confirms the validity of the hypothesis that there are significant differences between the average scores of the pilot group cases and the control group cases after the professional intervention using the emotional divorce risk scale in favor of the pilot group.

For the techno-sexual risk dimension, there are statistically significant differences between the average scores of the pilot and control groups after the professional intervention using the emotional divorce risk scale in favor of the pilot group. The arithmetic average of the pilot group amounted to (13.90) with a standard deviation (2.17), while the arithmetic average of the control group amounted to (25) with a standard deviation (3.08). The value of (T)was (12.702**), which is significant at significance of $(0.05)$. This indicates the effectiveness of the professional intervention program and confirms the validity of the hypothesis that there are significant differences between the average scores of the pilot group cases and the control group cases after the professional intervention using the emotional divorce risk scale in favor of the pilot group. Based on the previous table, we conclude that there are significant differences between the average scores of the pilot group and the control group after the professional intervention using the emotional divorce risk scale in favor of the pilot group. This indicates the effectiveness of the professional intervention program and confirms the validity of the hypothesis that there are significant differences between the average scores of the pilot group cases and the control group cases after the 
The Egyptian Journal of Social Work (EJSW) https://ejsw.journals.ekb.eg/e

ISSN: 2356-9204

Vol 11, Issue.1, January2021

professional intervention using the emotional divorce risk scale in favor of the pilot group. This is due to professional intervention efforts.

Study recommendations:

- There shall be simulation models for social workers in the offices of marital guidance and counseling and specialists of marital counseling, and online dialogue channels shall be opened between them to discuss the issues of social life.

- Holding training courses for those who are about to marry, so that marriage contract cannot be made unless the couple's certificates of attendance to the marital life preparation courses are annexed therewith. This procedure shall become mandatory just like the medical examination before marriage, which has proven its benefits and usefulness.

- Establishing or developing the official national bodies and mechanisms concerned with family affairs, connecting them to the highest executive authority in the state and supporting them with an appropriate budget.

- Supporting cooperation between national and Arab research and scientific institutions and centers interested in family studies and Arab and international organizations to collect statistics and data on the family according to criteria and classifications that take into account families' different patterns and environments, and conducting research, studies and field surveys on family status and the impact of contemporary changes thereon.

- Establishing specialized expert houses in social life to study the social phenomenon and contribute with social institutions in decision guidance and making.

\section{References:}

Abdo B. A. K., Hassan M. A. R. (2006). Using the Rehabilitative Preventive Approach in Building Positive Values Towards Reproductive Health, Journal of Studies of Social Work an Humanities, Helwan University, College of Social Work, p (20), c. (3).

Al-Bahi Z. M. A. (2004). Family-life learning requirements for Newly Formed Families, research published in the seventeenth annu Scientific Conference, Helwan University, Faculty of Social Work.

Al-Hakbani , S.,( 2013 ). Family Guidance Guide. Riyadh: King Fahd National Library.

Ali Saleh Jarwan \& Basem Mohammed Alfreha (2020), Emotional Divorce and its Relationship with Psychological Hardiness, International Journal of Education and Practice ,2020 Vol. 8, No. 1, ISSN(e): 2310-3868 ISSN(p): 2311-6897 DOI: $10.18488 /$ journal.61.2020.81.72.8. 
The Egyptian Journal of Social Work (EJSW) https://ejsw.journals.ekb.eg/e

ISSN: 2356-9204

Vol 11, Issue.1, January2021

Al-Otaiby N. M. (2018). A proposed Model to Confront the Problem Of Emotional Divorce in Saudi Society from the Perspective Of Social Group Work Methodology, research published in The Journal of Studies of Social Work and Humanities, Helwan University, College of Social Work, p. (50).

Al-Tanbary F. A. M. E. (2017). The Application of Positive Family

Dialogue Mechanisms in Social Group Work Program to Develop Wives 'A Ability to Deal with their Marital Problems, Social Work Magazine, The Egyptian Society of Social Workers, p. (57), c. (5).

Al Ubaidi BA, (2017) .The Psychological and Emotional Stages of Divorce, Journal of Family Medicine and Disease Prevention, J Fam Med Dis, 3:060.Volume 3 | Issue 3 DOI: 10.23937/2469- 5793/1510060.

Al-Zawawy A. H. A. (2011). A Proposed Role for the Social Group Work Specialist in Providing the Newlywed with Family Coping Skills in the Light of Contemporary Social, Economic and Technological Variables, a research published in the $24^{\text {th }}$ International Scientific Conference, vol. (4), Helwan University, Faculty of Social Work

Amiri S., et al (2015). Investigating Emotional Divorce on Family Performance, Journal of Applied Environmental and Biological Sciences ISSN: 2090-4274, J. Appl. Environ. Biol. Sci., 5(11S)782-786.

Arabia H. A. A. (2008). The Relationship of Disorders of lack of Sexual Desire Among Women with Marital Harmony, PhD Thesis, Ain Shams University, Faculty of Arts.

Attieh, N., (2009). Effectiveness of a Program for the Development of Effective Treatment in a Sample of Emotionally Divorced Couples. Dissertated Dissertation, Ain Shams University, Cairo.

Barnes, Gill Gorilla,( 2003). Family Therapy Over Time, Translated by Farideh Abbasi Dalouee, 2004, Mashhad, Arastu publications.

Bradford W. Wilcox\& Sacred Vows(2002).Public Purposes: Religion, the Marriage Movement, and Marriage Policy, (The Pew Forum on Religion and Public Life, 2002),

Charles D. Garvin, Lorraine M. Gutierrez (2004). Hand Book of Social Work With Group. New York, the Grilford Press.

Esere M.O. et al (2014). Obstacles and Suggested Solutions to Effective Communication in Marriage as Expressed by Married Adults in Kogi State, Nigeria, Procedia - Social and Behavioral Sciences 114 ( 2014 ) 584 - 592, 4th World Conference on Psychology, Counseling and Guidance WCPCG2013, Available online at www.sciencedirect.com.

Fahmy M. S., Attia E. A. (2003). Methodology of social group work between theoretical and practical skills, Alexandria, Modern University Office.

Golzari Mahmoud \& Bastani Sousan (2010) , Emotional divorce: Causes and Conditions of Mediator, Study of Social Problems of Iran journal, First year, No.3, autumn.

Hashem S. F. (2020). Practicing the life Model from the General Practice Perspective of Social Work in Relieving the Pressures Suffered by Divorced Women, A Research Published in The Journal of Studies of Social Work and Humanities, p. (50), vol. (3), Helwan University, Faculty of Social Work.

Kafafi, A.,(1999).Counseling and Psychosocial Therapy Communication Contextual Perspective. Cairo: Arab Thought House. Khanfar, F., 2. 


\begin{tabular}{||cr||}
\hline The Egyptian Journal of Social Work (EJSW) https://ejsw.journals.ekb.eg/e \\
ISSN: $2356-9204$ & Vol 11, Issue.1, January2021 \\
\hline \hline
\end{tabular}

Mansour H. M. (1992). Measuring the feeling of spouses' alienation as a basis for the diagnosis of marital conflict cases, a research published in the Sixth Scientific Conference, Helwan University, Faculty of Social Work.

RizkY. A. A. (2013). The role of social work in the field of family and Child protection, unpublished master thesis, Sudan University of Science and Technology, College of Graduate Studies.

Theresa Notare \& H. Richard McCord (2012). Marriage and the Family in the United States: Resources for Society A review of Research on the benefits generated from families rooted in Marriage. Secretariat of Laity, Marriage, Family Life and Youth, United States Conference of Catholic Bishops Washing to DC United States of America. 
The Egyptian Journal of Social Work (EJSW) https://ejsw.journals.ekb.eg/e ISSN: 2356-9204 Vol 11, Issue.1, January2021 